\title{
Hypoxia in Cancer and Fibrosis: Part of the Problem and Part of the Solution
}

\author{
Yair Romero 1,*(D) and Arnoldo Aquino-Gálvez 2,*(D) \\ 1 Facultad de Ciencias, Universidad Nacional Autónoma de México, Mexico City 04510, Mexico \\ 2 Instituto Nacional de Enfermedades Respiratorias "Ismael Cosío Villegas", Mexico City 14080, Mexico \\ * Correspondence: yair@ciencias.unam.mx (Y.R.); araquiga@yahoo.com.mx (A.A.-G.)
}

check for

updates

Citation: Romero, Y.; Aquino-Gálvez, A. Hypoxia in Cancer and Fibrosis: Part of the Problem and Part of the Solution. Int. J. Mol. Sci. 2021, 22, 8335. https://doi.org/10.3390/ ijms22158335

Academic Editor: Jung-Ae Kim

Received: 31 May 2021

Accepted: 27 July 2021

Published: 3 August 2021

Publisher's Note: MDPI stays neutral with regard to jurisdictional claims in published maps and institutional affiliations.

Copyright: (c) 2021 by the authors. Licensee MDPI, Basel, Switzerland. This article is an open access article distributed under the terms and conditions of the Creative Commons Attribution (CC BY) license (https:// creativecommons.org/licenses/by/ $4.0 /)$.

\begin{abstract}
Adaptive responses to hypoxia are involved in the progression of lung cancer and pulmonary fibrosis. However, it has not been pointed out that hypoxia may be the link between these diseases. As tumors or scars expand, a lack of oxygen results in the activation of the hypoxia response, promoting cell survival even during chronic conditions. The role of hypoxia-inducible factors (HIFs) as master regulators of this adaptation is crucial in both lung cancer and idiopathic pulmonary fibrosis, which have shown the active transcriptional signature of this pathway. Emerging evidence suggests that interconnected feedback loops such as metabolic changes, fibroblast differentiation or extracellular matrix remodeling contribute to HIF overactivation, making it an irreversible phenomenon. This review will focus on the role of HIF signaling and its possible overlapping in order to identify new opportunities in therapy and regeneration.
\end{abstract}

Keywords: hypoxia-inducible factors; lung cancer; idiopathic pulmonary fibrosis; regeneration

\section{Hypoxia Adaptation and Signaling}

The capacity to detect oxygen levels is essential for the survival of organisms and cells, especially within the lung. When the cell has enough oxygen (normoxia), alpha subunits are degraded by the ubiquitin-proteasome pathway with the intervention of Von Hippel Lindau protein (VHL). This interaction with VHL depends on available oxygen as the substrate of hydroxylation reactions by prolyl hydroxylases (PHD1-3) [1-4]. Instead, when the oxygen concentration declines, these reactions are inhibited, which causes alpha subunit accumulation in the cytoplasm and subsequent translocation to the nucleus, where it heterodimerizes with the $\beta$ subunit [5]. These heterodimers within the nucleus recognize the sequence TACGTG, called the hypoxia response element (HRE), located in the promoter regions of genes involved in hematopoiesis, angiogenesis, iron transport, glucose consumption, MEC synthesis, cell growth and differentiation, among other functions [6].

HIF- $1 \alpha$ was identified by examining the regulatory mechanism of erythropoietin thirty years ago [7-9]. Later, HIF-2 $\alpha$ was recognized by comparing the sequence with HIF- $1 \alpha$ and it was found with the endothelium (EPAS1) $[10,11]$. The third member of this family was identified in 1998 [12]. The three isoforms share heterodimers with a beta subunit constitutively expressed, called HIF-1 $\beta$ (also known as ARNT); see Figure 1.

\section{Structure and Functional Domains of Hypoxia-Inducible Factors}

The structure of these proteins consists of different domains:

a. Basic helix-loop-helix (bHLH). This is a basic region followed by two alpha-helices separated by a variable loop region, and this region confers the ability to bind DNA as homodimers or heterodimers, which is found in other transcription factors [13].

b. PAS domains. PAS-A and PAS-B domains also build a stable heterodimer that enables robust DNA binding. In the PAS-B structure, a central $\beta$-sheet provides a hydrophobic surface for HIF-1 $\beta$ that is conserved among the HIF $\alpha$ isoforms [14]. 
c. Oxygen-dependent degradation domain (ODDD). This domain is responsible for degradation by the ubiquitin-proteome system, located 200 amino acids in the central region and has two functional domains: N-terminal (NODD) and the C-terminal (CODD) [15]. The hydroxylation of NODD is more sensitive to hypoxia than CODD; thus, it is possible to block them differentially [16].

d. The transactivation domain (TAD). These domains (N-TAD and C-TAD) contain binding sites for other proteins such as transcription coregulators essential in determining what type of genes will be expressed due to specific recruitment $[17,18]$.

e. Nuclear localization signal (NLS). $\alpha$ and $\beta$ subunits have two nuclear localization sequences in N- and C-terminal domains [19]. Direct interaction of HIFs with importins $1 \alpha, 3 \alpha, 5 \alpha$ and $7 \alpha$ has been described, and this interaction depends on a nuclear localization signal within the C-terminal region [20]. Furthermore, an additional interaction site has been reported with importins 4 and 7, which is more efficient than NLS interaction [21].

f. The nuclear export signal (NES), located in amino acids $616-658$, has been reported to be regulated by MAPK phosphorylation [22].

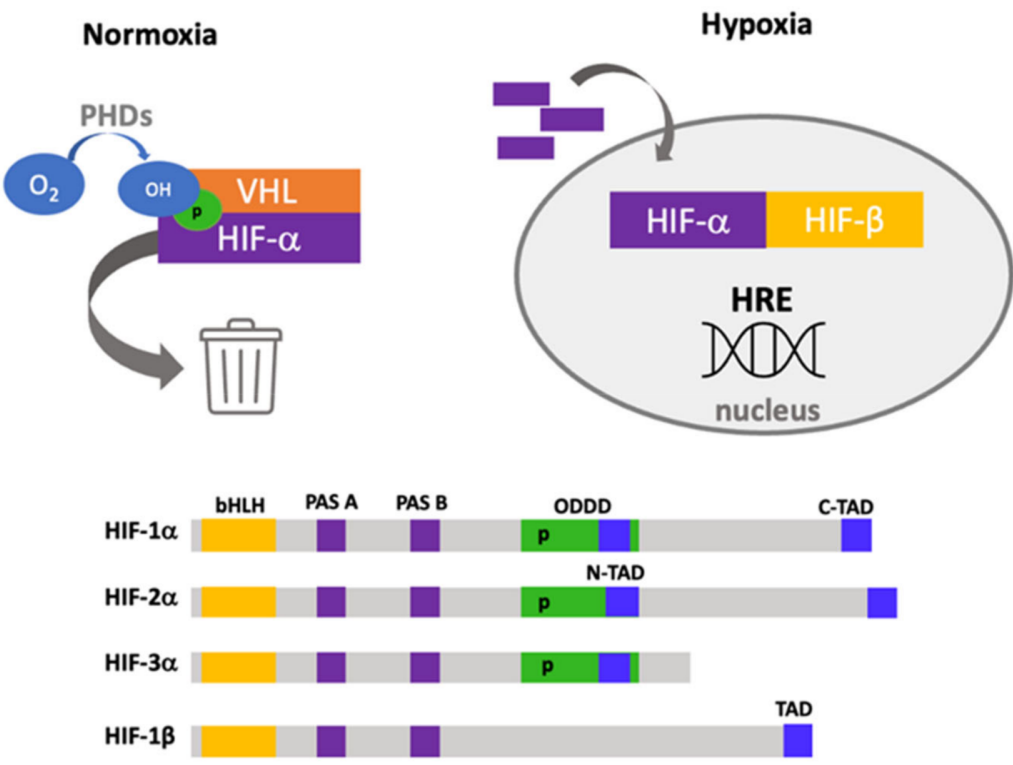

Figure 1. Hypoxia adaptation by HIF system. Hydroxylation reactions in proline residues of alpha subunits (HIF- $1 \alpha$, HIF- $2 \alpha$ and HIF- $3 \alpha$ ) depend on available oxygen (normoxia); these reactions cause its degradation by interaction with Von Hippel Lindau protein (VHL). The decrease in oxygen concentration inhibits HIF- $\alpha$ hydroxylation and induces its accumulation in the cytoplasm and subsequent translocation to the nucleus, where it heterodimerizes with the HIF-1 $\beta$ (hypoxia). This heterodimer is able to bind to hypoxia response elements (HRE) found in promoters of diverse genes. Structure and functional domains of hypoxia-inducible factors (below).

\section{Cancer Hallmarks Associated with Hypoxia}

Lung cancer and idiopathic pulmonary fibrosis (IPF) compromise the lung parenchyma, with an irreversible loss of gas exchange; solid tumors and fibroblast foci have limited nutrient supply due to the dense microenvironment; counterintuitively, cells still proliferate, causing disease progression. In this context, hypoxia adaptation could represent a coherent link between cell proliferation and the interruption of the nutrient supply [23]. Although the relationship between cancer and fibrosis has been reported [24-27], hypoxia has not been pointed out as the cause of this association. Nevertheless, there is a compelling body of literature about hypoxia in both diseases. Therefore, it is necessary to identify the elements described in the cancer literature and the potential overlap. 


\subsection{Hypoxic Microenvironment in Tumors}

Initially, the role of hypoxia in cancer was restricted to the "tumor microenvironment" of solid tumors. Tumors have necrotic areas close to areas with gradients of oxygen related to the distance to the blood vessels. Although these gradients are also present in normal tissues, in cancer, these gradients decline abruptly and chronically $[28,29]$. Furthermore, the cyclic hypoxia offers a strong activation of the HIF pathway, which, in turn, helps tumor cells to survive adverse conditions such as cytotoxic therapy [30,31]. Dewhirst et al. explain this overactivation with an analogy about the frequency of the cycles of tides and waves and how these impact on the coast, where tides represent the degree of hypoxia and waves the high-frequency fluctuations of the blood flux. When there is an overlap, overactivation of HIF pathway occurs [30,32]. An important example of this association between cancer and the cyclic hypoxia might be appreciated in cancer patients suffering from obstructive sleep apnea (OSA); this association participates in increasing the incidence and mortality of cancer [33]. Several studies have confirmed that exposure to cyclic hypoxia increases cancer stem cell markers, as well as features related to metastasis [34-36]. It has even been suggested that the aggressiveness in melanoma can be mediated by TGF- $\beta$ (a well-known pro-fibrotic cytokine) [37]. This association is also present in other diseases, such as hypertension and type 2 diabetes, in which there is a particular adaptation of HIF signaling resulting in the overactivation of HIF- $1 \alpha$ and downregulation of HIF- $2 \alpha$ and a consequent increase in reactive oxygen species (ROS) [38,39]. ROS are an integral component of the tumor microenvironment as they engage HIF stabilization and immunity regulation $[40,41]$. Thus, the kinetics and integration of the response to hypoxia in the tumor microenvironment are complex.

\subsection{Hypoxia-Induced Metabolic Changes}

In addition to these hypoxic areas, another widely studied mechanism is the metabolic reprogramming of cancer cells, described almost 100 years ago by Otto Warburg [42]. From initial observations about increased glycolysis in tumors even in the presence of oxygen, this phenomenon has been implicated with the intense proliferation of cancer cells $[43,44]$. The molecular basis of this adaptation is similar to the fermentation in hypoxic conditions, which was clarified by the understanding of HIF signaling and the role of mitochondria in its activation [40]. This bioenergetic switch induces the expression of multiple genes involved in glycolysis; although this phenomenon goes beyond a change in glucose metabolism, this implies integration with biosynthetic pathways [45-47]. For example, other intermediates of the tricarboxylic acid cycle (TCA) are used in macromolecule synthesis [47]. In the same line, cancer cells in general show an addiction to glutamine; its role transitions from being a donor in the biosynthesis of nucleotides and amino acids to the activation of the mTOR complex (which will be discussed later) [48]. With this knowledge, glutaminolysis has been incorporated into metabolic cancer treatment [49-51].

\subsection{Integration of HIFs Signaling in Lung Cancer}

Despite the considerable growth of the hypoxia field, our understanding remains restricted in how HIF circuitries are integrated and especially by the fact that distinct alpha subunits can elicit different responses. HIF- $1 \alpha$ has been reported in a large number of cancer types; its primary association is in an acute response with the expression of glucose transporters, glycolytic enzymes and growth factors [52]. HIF- $2 \alpha$ plays a predominant role in chronic hypoxia and angiogenesis [53]. This could be partially explained by the fact that HIF- $2 \alpha$ is relatively more resistant to factor-inhibiting HIF1 (FIH-1) [54]. Although there is a certain redundancy between HIF1 and 2, HIF- $2 \alpha$ has a predilection for MMP14, EPO and PAI-1 [55-57]. In addition, a loss of HIF-2 $\alpha$ causes a fatal respiratory distress syndrome in mice since HIF- $2 \alpha$ regulates the activation of VEGF in lung maturation and surfactant production by type 2 alveolar cells [58]. In the context of lung cancer, HIF- $1 \alpha$ and HIF- $2 \alpha$ are overexpressed in both the cytoplasm and the nucleus and are associated with poor prognosis [59]. The HIF-3 $\alpha$ locus allows extensive alternative splicing, 
producing several variants; this variety confers HIF-3 $\alpha$ a broader and complex role [60]. For instance, HIF- $3 \alpha 1$ inhibits transcriptional activation by the lack of a transactivation domain (TAD), while HIF-3 $\alpha 4$ inhibits nuclear translocation [61]. However, knock-down of HIF-3 $\alpha$ induces downregulation of the HIF signature [61]. Recently, we found that treatment with a combination of 2-methoxyestradiol and sodium dichloroacetate in A549 cells reduces hypoxia-induced resistance at $1 \% \mathrm{O}_{2}$ for $72 \mathrm{~h}$, mainly by the effect in HIF- $3 \alpha$ and a modest contribution of HIF-1 $\alpha$ [62]. This exemplifies how hypoxia signaling is orchestrated by distinct members on the pathway.

An essential element in this adaptation is that hypoxia can directly alter the epigenetic landscape. It has been reported, in cancer and aging, that there is a global loss of methylation marks along with hypermethylation in specific promoters [63,64]. For example, the hypoxic condition affects DNA demethylation by reducing TET enzyme activity [65]. Furthermore, hypoxia-induced chromatin remodeling might be mediated by histone deacetylases (HDACs) and histone demethylase enzymes, with a Jumanji-C (JmjC) domain [66,67]. Definitively, epigenetics denotes the possibility of the integration of microenvironment signals with metabolism. Thus, hypoxia adaptation by HIF signaling (mainly overactivation of HIF-1 $\alpha$ ) promotes aggressiveness by several mechanisms in cancer cells but without establishing if there is a cause of chronic exposure [52,68].

\subsection{Interconnected Pathways with Hypoxia}

The molecular sensors involved in stress responses have feedback mechanisms that are necessary to adapt to the microenvironment. An example of these interconnections is the link between mTOR and hypoxia. mTOR complex kinase lies at the nexus of many signaling pathways involved in cell growth by protein synthesis and inhibition of autophagy [69]. Although both are master regulators of metabolism, it is difficult to understand that mTOR is inhibited by hypoxia conditions (typically in "normal cells"), and hypoxiainducible factors' synthesis is mTOR-dependent. This makes sense in a gradual synchronic response: at the beginning, moderate hypoxia stress may act as an obstacle for survival and proliferation, but, later, severe hypoxia could drive the assortment of mutations that confer resistance to cell death, such as TP53 mutations [70,71]. It is important, in this first scenario, to consider the possibility to reduce autophagy in order to eliminate a probable route of nutrient supply [72]. Otherwise, mTOR and the unfolding protein response (UPR) contribute to hypoxia tolerance [73-75]. In this chronic exposure, the participation of hypoxia in tumorigenesis is significant; for example, in patients with non-small-cell lung cancer, recurrent mutations of the epidermal growth factor receptor (EGFR) have been associated with hypoxia [76,77]. Thus, hypoxia pathway overactivation corresponds to an activation of alternative redundant pathways involved in cell survival [3,78]. Moreover, it is essential to note that the lack of oxygen is not the only mechanism behind HIF activation. Additionally, this effect can be observed by oncogenes or mutations in tumor suppressors such as PTEN, VHL and p53 or directly by redox imbalance $[79,80]$. Moreover, this activation of HIFs, either oxygen-dependent or independent, can be found in the same tumor [81].

\subsection{Hypoxia and Extracellular Matrix Remodeling}

Generally, cancer progression is accompanied by dense accumulations of the extracellular matrix that supports the structure of the tumor (stroma). The stroma is synthesized by cancer-associated fibroblasts (CAF); these cells are phenotypically different from normal fibroblasts and acquire markers such as alpha smooth muscle actin ( $\alpha \mathrm{SMA})$, fibroblast activation protein (FAP), $\alpha 1 \beta 1$ integrin and Thy-1 [82]. Notwithstanding, this phenomenon makes the overlapping between cancer and fibrosis clear as there are some contradictions about the role of these fibroblasts in cancer. The different CAF subpopulations depend on their origin and on the signals in the microenvironment [83]. At present, several origins have been described, such as epithelial to mesenchymal transition (EMT), activation of resident fibroblasts, endothelial to mesenchymal transition (EndMT) and circulating bone 
marrow-derived cells [84]. In terms of the microenvironment, stiffness of the extracellular matrix or hypoxia drive the activation of $\mathrm{CAF}$, where feedback loops that support the progression of cancer have been established. Several reports are pointing out the role of MMPs and specific growth factors (mainly TGF- $\beta$ ) in the remodeling of the extracellular matrix (ECM); currently, nevertheless, it is becoming clear how this tissue remodeling integrates mechanical forces. For example, the ECM produced by CAFs forms a capsule adjacent to cancer cells; this capsule actively compresses cancer cells by actomyosin contractility forces [85]. Furthermore, the tumor is broader than epithelial cells and CAFs; there also exists a complex interaction of distinct cell populations (cancer stem cells, endothelial cells, inflammatory cells, pericytes) and the clonal heterogeneity that could be explained (at least in part) by hypoxia gradients [28].

In summary, from this relation between cancer and hypoxia, we can extract concepts such as a hypoxic microenvironment in tumors, cyclic hypoxia, metabolic changes, extracellular matrix remodeling and interconnections that can be extended to fibrosis and vice versa (Table 1).

Table 1. Cancer hallmarks associated with hypoxia.

\begin{tabular}{ccrr}
\hline Hallmark & Cause or Effect & Associated with Fibrosis & References \\
\hline Tumor microenvironment & Cause & - & {$[28,52-54,60,65,66,68,82,86,87]$} \\
\hline Metabolic switch & Effect & + & {$[30,31,42-45,51,59,62]$} \\
\hline Cyclic hypoxia & Cause & + & {$[32-39]$} \\
\hline Cancer stem cell & Effect & + & {$[34-36]$} \\
\hline Cancer-associated fibroblasts & Effect & +++ & {$[67,82-84]$} \\
\hline ECM remodeling & Effect/Cause & +++ & {$[55,67,83]$} \\
\hline
\end{tabular}

\section{Hypoxia Signaling Overlap in Cancer and Fibrosis?}

Historically, it has been described that idiopathic pulmonary fibrosis increases the risk of developing cancer. IPF increases the risk to $20 \%$, and the fibrotic lesion areas have the highest incidence of tumors $[25,88]$. However, the link to this association is unclear. In general, the cause has changed over time; for example, the first association was smoking habits, which was disregarded [89]. Later, inflammation was proposed as a cause; nowadays, it does not have a major role in the pathogenesis of IPF [90]. Here, we postulate that this association, at least in part, is due to hypoxia with nodes that participate in progression (Figure 2).

\section{Cancer}

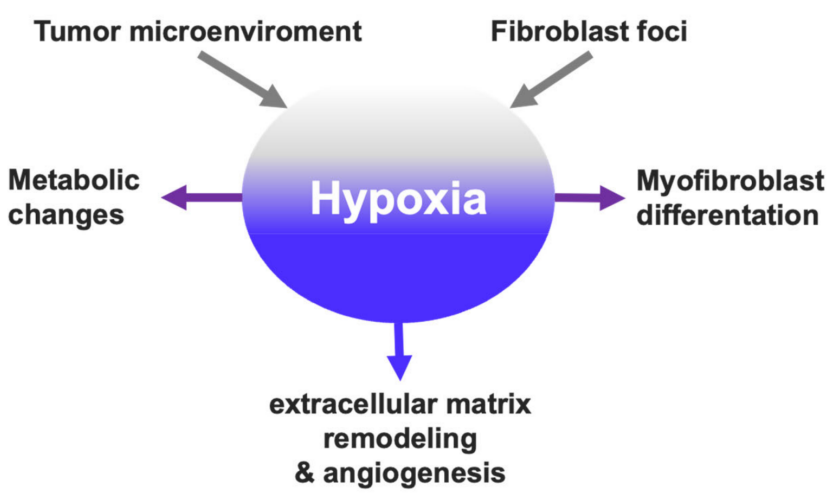

Figure 2. Hypoxia drives the progression in cancer and fibrosis. Hypoxia is an important part in the integration of the microenvironment signals; both tumors and fibroblast foci induce an activation of hypoxia and this in turn activates different mechanisms involved in its progression. 


\subsection{Hypoxia in the Pathophysiology of Idiopathic Pulmonary Fibrosis}

In brief, the pathophysiology of IPF is caused initially by an aberrant response of the alveolar epithelium [90,91]. This aberrant response is forced by a stochastic profibrotic agerelated epigenetic drift [92-94]. These cells are found in close relationship with active sites of fibrogenesis sites (fibroblast foci) and are responsible for the secretion of many mediators for fibroblast recruitment/activation, such as PDFG, TGF- $\beta$, MMP7, OPN, endothelin- 1 and more [95]. It is important to note that these markers have also been associated with hypoxia in cancer $[26,96]$. For example, MMP7 and MMP14 (also known as MT1-MMP) participate in metastasis, and their increase is associated with a hypoxic microenvironment [86]. In IPF, MMP7 was described as a profibrotic biomarker, and its expression is in a relationship with OPN increase, which is also associated with cancer and hypoxia [87,97-99]. In the case of MMP14, we recently published findings indicating that it protects against fibrosis by preventing the senescence of alveolar type 2 cells [100]. Although its expression is dependent on HIF- $2 \alpha$, it has not been established in IPF [55]. Interestingly, HIF- $2 \alpha$ and MMP14 participate in the embryonic development of lung through the integration of pulmonary vasculature and alveoli; knockout mice for these proteins confirm that the lethality is due to inadequate alveolarization $[58,101]$. This process is also recapitulated in regeneration and will be discussed later.

Additionally, the role of other cell populations (in addition to epithelial cells and fibroblasts) has been little studied in IPF. However, it has been reported that there is a population of macrophages that can promote fibrosis through immunological modulation [102]. During early events of fibrosis, macrophages have been implicated in the activation of host defense and profibrotic mechanisms [103]. Furthermore, a hypoxic microenvironment has an altered metabolite composition that promotes the activation of immune cells [104]. Accordingly, the link might be through elevated mitochondrial ROS or TCA cycle metabolites already involved in the regulation of immune cells [104,105].

\subsection{Effects of Hypoxia on the Alveolar Epithelium}

Further effects of hypoxia on alveolar epithelial cells include increased surfactant production, disruption of cytoskeleton integrity and apoptosis [106-108]. The adaptation mechanisms of these cells depend on the severity as well as on the duration of hypoxia, from adjusting ATP consumption in short periods to epithelial to mesenchymal transition (EMT) or cell death in chronic exposure [108]. One speculative feedback between hypoxia and fibrosis is that hypoxic conditions could provoke an impairment of surfactant activity and the abnormal remodeling of the alveolar space, suggested as an early marker of fibrosis, associated with aging [109-112]. Moreover, after $48 \mathrm{~h}$ of hypoxia, alveolar epithelial cells type 2 (AEC2) activate apoptosis, which promotes fibrosis [107,113]. In addition, surviving epithelial cells are an additional source of fibroblasts through the EMT phenomenon, which has been consolidated in the pathophysiological basis of cancer and fibrosis $[26,27,67]$.

\subsection{Profibrotic Feedback Loops Related to Hypoxia}

Even though epithelial cells play a leading role in the onset of the disease, the IPF progression depends on the establishment of profibrotic feedback loops, where hypoxia is implicated. The basis of this notion is that exacerbated extracellular matrix deposition in fibroblast foci promotes hypoxia and vice versa (Figure 3). Again, the microenvironment in the fibroblast foci of IPF determines fibroblast activation by the relation between the stiffness of the ECM and the degree of hypoxia. Evidence indicates that IPF lungs show transcriptional activation of hypoxia (mainly HIF-1 $\alpha$ ), and the knockout mice for HIF- $1 \alpha$ showed reduced lung fibrosis $[114,115]$. Furthermore, aggressive phenotypic changes in fibroblasts can be attributed to hypoxia. For example, loss of Thy- 1 has been associated with a profibrotic phenotype that favors proliferation, migration, ECM secretion and TGF- $\beta$ signaling [116]. This loss has been reported to be due to hypoxia-induced hypermethylation by hypoxia [117]. In cancer, Thy-1 has been proposed as a tumor suppressor, suggesting an overlapping role in both diseases $[118,119]$. In addition, in an integral overview 
(measuring the three alpha subunits), IPF fibroblasts showed specific hypermethylation of HIF-3 $\alpha$, which indicates that the lack of HIF- $3 \alpha$ causes the overactivation of hypoxia signaling and increases differentiation to myofibroblasts [120]. Thus, IPF fibroblasts have epigenetic changes, perhaps associated with aging, which cause their overactivation [121]. Furthermore, it has been suggested that fibroblasts form a reticulum that infiltrates the lung parenchyma, similar to a neoplasm $[122,123]$.

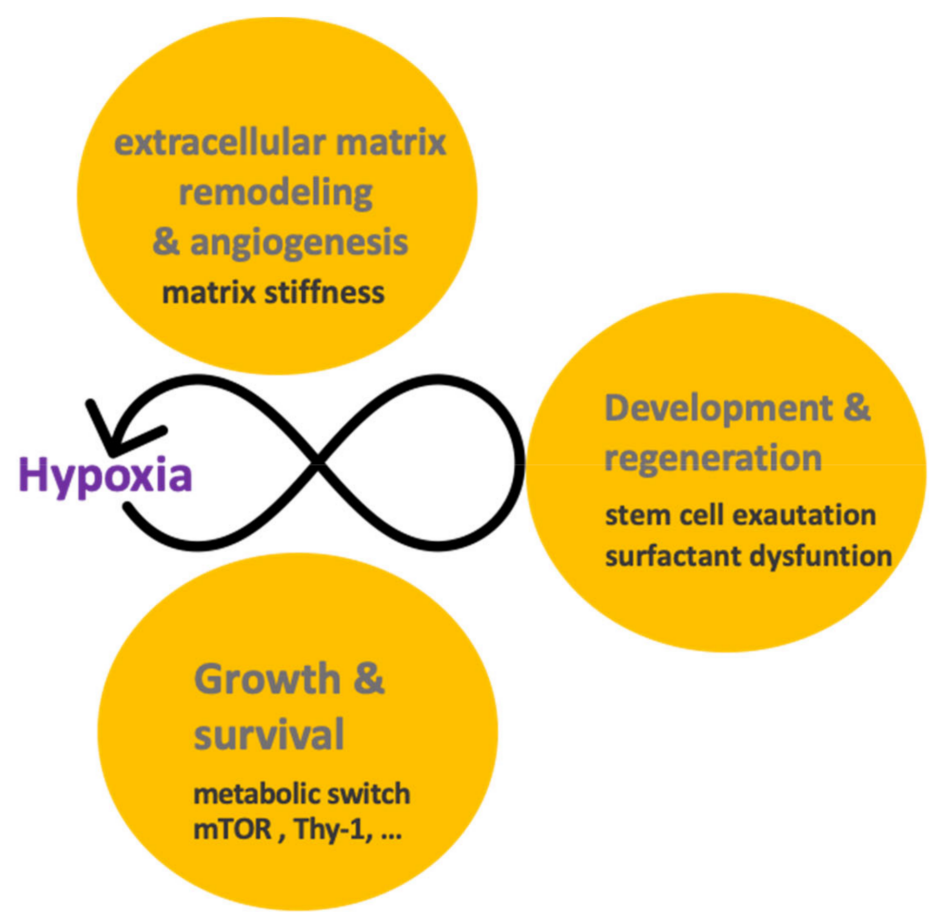

Figure 3. Persistent hypoxia activation. In cancer and fibrosis, hypoxia is a key participant in several processes that have feedback loops, especially when these processes have dysfunctions that promote hypoxia perpetuation (in black).

In a similar way to cancer, cyclic hypoxia increases the aggressiveness of fibrosis in patients with obstructive sleep apnea (OSA). For example, a study in the bleomycininduced fibrosis model shows that cyclic hypoxia by redox imbalance increases the severity of the lesions and amplifies the collagen deposition, with a consequent increase in ECM stiffness [124]. Although the molecular mechanism of this deterioration remains unknown, the possibility of shared common pathogenetic pathways suggests that the management of these "comorbidities" is equally crucial in IPF treatment $[125,126]$.

In addition, fibroblast foci have characteristics expected in a hypoxic environment, such as anaerobic metabolism. Although metabolic change is a field modestly addressed in idiopathic pulmonary fibrosis, it is involved in the survival of cells against nutrient stress, differentiation to myofibroblasts and collagen production [106,127,128]. Lactic acid, from anaerobic metabolism, has been proposed as an important mediator of myofibroblast differentiation through the $\mathrm{pH}$-dependent activation of TGF- $\beta[129,130]$. Myofibroblasts from IPF have increased glycolysis and increased differentiation, mediated by HIF- $1 \alpha$ and TGF- $\beta$ [131]. It has also been shown that during aging, an increase of GLUT1 promotes fibrogenesis [132]. In summary, these metabolic changes mediate a transition from oxidative to glycolytic metabolism, similar to cancer $[133,134]$.

Therefore, hypoxia signaling is overactivated in lung tumors and pulmonary fibrotic injuries, with profound alterations of several pathways that are interconnected (Tables 1 and 2). In this context, hypoxia supports disease progression mainly by its role in the survival and the establishment of profibrotic loops. However, the potential role in regeneration is exciting. 
Table 2. Fibrosis hallmarks associated with hypoxia.

\begin{tabular}{ccrr}
\hline Hallmark & Cause or Effect & Associated with Cancer & References \\
\hline Fibroblast foci & Cause & - & {$[114,115,117,120,129,130]$} \\
\hline Metabolic switch & Effect & +++ & {$[129,131-134]$} \\
\hline Cyclic hypoxia & Cause & + & {$[124,125]$} \\
\hline Fibroblast activation/differentiation & Effect & + & {$[115,117,120,129,131,132]$} \\
\hline Stem cell & Effect & ++ & {$[135-139]$} \\
\hline ECM remodeling & Effect/Cause & + & {$[115,117,120]$} \\
\hline
\end{tabular}

\section{Nothing in Hypoxia Signaling Makes Sense except in Light of Regeneration and Development}

The adult lung is a largely quiescent tissue; the alveolar epithelium has a turnover of only $7 \%$ of alveoli per year [140]. This epithelium is responsible for gas exchange and is composed exclusively of alveolar epithelial cells type 1 and 2 . The challenge in respiratory diseases is the continuous identification of nodes that lead to a pathological state such as cancer or fibrosis [141]. Consequently, it will be significant to investigate how epithelial cells can respond effectively to hypoxia injury by activating stem/progenitor populations. In the adult lung, the interaction of alveolar epithelial cells type 2 and mesenchymal cells (fibroblasts) is responsible for recovering the alveolar epithelium when an injury occurs $[142,143]$. In this sense, these cells, as facultative progenitors, require a microenvironment or "niche" that detonates their function [144]. Several studies reported that hypoxia and HIFs have a crucial role in promoting an undifferentiated state by the interaction with their respective niches by OCT4 or Sox2, or signaling pathways such as Notch and Wnt $[135,145-147]$. One example of these niches can be found in the bone marrow, where hematopoietic stem cells reside in regions with low oxygen tension [148]. In lung development, this phenomenon also occurs, where oxygen availability determines the patterning and morphogenesis of the trachea, as observed in studies of D. melanogaster [149,150]. In addition, HIF signaling regulates alveologenesis during development, predominantly by HIF- $2 \alpha$ and HIF- $3 \alpha[58,151]$.

Hypoxia overactivation suggests that regeneration has been initiated but not completed, which is due to recurrent injury or inadequate regeneration (Figure 3). For example, during lung regeneration, hypoxia develops a level of response that determines epithelial fate; after influenza infection, these lesions have an acute activation, while in IPF cells, hypoxia is severe, with changes in the behavior of epithelial cells, such as lower surfactant production [136]. Perturbations associated with aging, mutations and epigenetic modifications could remove the breaks on hypoxia signaling in cancer and fibrosis, which could be the cause of these aberrant persistence of stem cell states [152]. For example, in fibrosis, where cells attempt to restore the lung, the HIF pathway signature is also present in the stem cell states $[137,153]$. In the same line, in IPF, a recent paper highlights a particular population of basaloid cells in the surface of fibroblasts foci that coexpress epithelial, mesenchymal, senescence and developmental markers [154]. Further transition states have been reported due to mechanical forces or spontaneous forms that need to be incorporated $[155,156]$. Understanding lung regeneration is a fundamental challenge for future therapies.

Finally, integrating this perspective will offer the possibility of new therapies. For example, mesenchymal stem cells cultured in hypoxia reach senescence later [138]. In the same cells, hypoxia pretreatment improves their transplantation in a fibrosis model [139]. It is important to note that the relationship between cancer and fibrosis makes clear the possibility of using the same treatments, such as the current IPF therapies, pirfenidone and nintedanib, that are also active in lung cancer [25]. Furthermore, there is the possibility of using drugs activated by enzymatic reduction in hypoxic tissue [157]. 
In summary, this review provides the basis (along with other papers) to integrate the hypoxia response from the molecular level with the intercommunicated pathways that form some of the circuitries in respiratory diseases.

\section{Conclusions}

Lung cancer and pulmonary fibrosis (particularly IPF) are chronic diseases associated with hypoxia and represent a significant public health problem. This review makes clear the relationship that exists between cancer and fibrosis through hypoxia, not only in a transcriptionally active signature but also in feedback loops, which may be the basis for progression in these two diseases. Although the hypoxia response is necessary for the regeneration process, if it persists, it may lead to activation of feedback loops related to progression, which generally overlap between these diseases. To face this challenge in cancer and fibrosis, an integrated understanding of the crosstalk between the development and regeneration of stem cells with the external environment is required.

Author Contributions: Y.R. and A.A.-G. wrote the manuscript. Both authors have read and agreed to the published version of the manuscript.

Funding: Yair Romero's work was supported by CONACYT \#51219. Arnoldo Aquino-Gálvez's work was supported by CONACYT \#194162.

Institutional Review Board Statement: Not applicable.

Informed Consent Statement: Not applicable.

Acknowledgments: We thank Angelica Sofia Martinez Ramirez for reviewing the manuscript.

Conflicts of Interest: The authors declare that they have no conflict of interest.

\section{References}

1. Cockman, M.E.; Masson, N.; Mole, D.R.; Jaakkola, P.; Chang, G.W.; Clifford, S.C.; Maher, E.R.; Pugh, C.W.; Ratcliffe, P.J.; Maxwell, P.H. Hypoxia inducible factor-alpha binding and ubiquitylation by the von Hippel-Lindau tumor suppressor protein. J. Biol. Chem. 2000, 275, 25733-25741. [CrossRef]

2. Maxwell, P.H.; Wiesener, M.S.; Chang, G.W.; Clifford, S.C.; Vaux, E.C.; Cockman, M.E.; Wykoff, C.C.; Pugh, C.W.; Maher, E.R.; Ratcliffe, P.J. The tumour suppressor protein VHL targets hypoxia-inducible factors for oxygen-dependent proteolysis. Nature 1999, 399, 271-275. [CrossRef] [PubMed]

3. Shimoda, L.A.; Semenza, G.L. HIF and the lung: Role of hypoxia-inducible factors in pulmonary development and disease. Am. J. Respir. Crit. Care Med. 2011, 183, 152-156. [CrossRef]

4. Schofield, C.J.; Ratcliffe, P.J. Oxygen sensing by HIF hydroxylases. Nat. Rev. Mol. Cell Biol. 2004, 5, 343-354. [CrossRef] [PubMed]

5. Semenza, G.L. Pharmacologic Targeting of Hypoxia-Inducible Factors. Annu. Rev. Pharmacol. Toxicol. 2019, 59, 379-403. [CrossRef] [PubMed]

6. Olenyuk, B.Z.; Zhang, G.-J.; Klco, J.M.; Nickols, N.G.; Kaelin, W.G., Jr.; Dervan, P.B. Inhibition of vascular endothelial growth factor with a sequence-specific hypoxia response element antagonist. Proc. Natl. Acad. Sci. USA 2004, 101, 16768-16773. [CrossRef]

7. Semenza, G.L.; Nejfelt, M.K.; Chi, S.M.; Antonarakis, S.E. Hypoxia-inducible nuclear factors bind to an enhancer element located $3^{\prime}$ to the human erythropoietin gene. Proc. Natl. Acad. Sci. USA 1991, 88, 5680-5684. [CrossRef]

8. Semenza, G.L.; Wang, G.L. A nuclear factor induced by hypoxia via de novo protein synthesis binds to the human erythropoietin gene enhancer at a site required for transcriptional activation. Mol. Cell. Biol. 1992, 12, 5447-5454. [CrossRef] [PubMed]

9. Wang, G.L.; Semenza, G.L. General involvement of hypoxia-inducible factor 1 in transcriptional response to hypoxia. Proc. Natl. Acad. Sci. USA 1993, 90, 4304-4308. [CrossRef]

10. Tian, H.; Mcknight, S.L.; Russell, D.W. Endothelial PAS domain protein 1 (EPAS1), a transcription factor selectively expressed in endothelial cells. Genes Dev. 1997, 11, 72-82. [CrossRef] [PubMed]

11. Ema, M.; Taya, S.; Yokotani, N.; Sogawa, K.; Matsuda, Y.; Fujii-Kuriyama, Y. A novel bHLH-PAS factor with close sequence similarity to hypoxia-inducible factor 1alpha regulates the VEGF expression and is potentially involved in lung and vascular development. Proc. Natl. Acad. Sci. USA 1997, 94, 4273-4278. [CrossRef] [PubMed]

12. Gu, Y.Z.; Moran, S.M.; Hogenesch, J.B.; Wartman, L.; Bradfield, C.A. Molecular characterization and chromosomal localization of a third alpha-class hypoxia inducible factor subunit, HIF3alpha. Gene Expr. 1998, 7, 205-213.

13. Wang, G.L.; Jiang, B.H.; Rue, E.A.; Semenza, G.L. Hypoxia-inducible factor 1 is a basic-helix-loop-helix-PAS heterodimer regulated by cellular $\mathrm{O}_{2}$ tension. Proc. Natl. Acad. Sci. USA 1995, 92, 5510-5514. [CrossRef]

14. Erbel, P.J.A.; Card, P.B.; Karakuzu, O.; Bruick, R.K.; Gardner, K.H. Structural basis for PAS domain heterodimerization in the basic helix-loop-helix-PAS transcription factor hypoxia-inducible factor. Proc. Natl. Acad. Sci. USA 2003, 100, 15504-15509. [CrossRef] 
15. Huang, L.E.; Gu, J.; Schau, M.; Bunn, H.F. Regulation of hypoxia-inducible factor 1alpha is mediated by an $\mathrm{O}_{2}$-dependent degradation domain via the ubiquitin-proteasome pathway. Proc. Natl. Acad. Sci. USA 1998, 95, 7987-7992. [CrossRef]

16. Chowdhury, R.; Leung, I.K.H.; Tian, Y.-M.; Abboud, M.I.; Ge, W.; Domene, C.; Cantrelle, F.-X.; Landrieu, I.; Hardy, A.P.; Pugh, C.W.; et al. Structural basis for oxygen degradation domain selectivity of the HIF prolyl hydroxylases. Nat. Commun. 2016, 7, 12673. [CrossRef]

17. Ruas, J.L.; Poellinger, L.; Pereira, T. Functional analysis of hypoxia-inducible factor-1 alpha-mediated transactivation. Identification of amino acid residues critical for transcriptional activation and/or interaction with CREB-binding protein. J. Biol. Chem. 2002, 277, 38723-38730. [CrossRef]

18. Hu, C.-J.; Iyer, S.; Sataur, A.; Covello, K.L.; Chodosh, L.A.; Simon, M.C. Differential Regulation of the Transcriptional Activities of Hypoxia-Inducible Factor 1 Alpha (HIF-1 $\alpha$ ) and HIF-2 $\alpha$ in Stem Cells. Mol. Cell. Biol. 2006, 26, 3514-3526. [CrossRef] [PubMed]

19. Kallio, P.J.; Okamoto, K.; O’Brien, S.; Carrero, P.; Makino, Y.; Tanaka, H.; Poellinger, L. Signal transduction in hypoxic cells: Inducible nuclear translocation and recruitment of theCBP/p300 coactivator by the hypoxia-induciblefactor- $1 \alpha$. EMBO J. 1998, 17, 6573-6586. [CrossRef]

20. Depping, R.; Steinhoff, A.; Schindler, S.G.; Friedrich, B.; Fagerlund, R.; Metzen, E.; Hartmann, E.; Köhler, M. Nuclear translocation of hypoxia-inducible factors (HIFs): Involvement of the classical importin alpha/beta pathway. Biochim. Biophys. Acta 2008, 1783, 394-404. [CrossRef] [PubMed]

21. Chachami, G.; Paraskeva, E.; Mingot, J.M.; Braliou, G.G.; Görlich, D.; Simos, G. Transport of hypoxia-inducible factor HIF-1 $\alpha$ into the nucleus involves importins 4 and 7. Biochem. Biophys. Res. Commun. 2009, 390, 235-240. [CrossRef]

22. Mylonis, I.; Chachami, G.; Paraskeva, E.; Simos, G. Atypical CRM1-dependent nuclear export signal mediates regulation of hypoxia-inducible factor- $1 \alpha$ by MAPK. J. Biol. Chem. 2008, 283, 27620-27627. [CrossRef]

23. Papandreou, I.; Cairns, R.A.; Fontana, L.; Lim, A.L.; Denko, N.C. HIF-1 mediates adaptation to hypoxia by actively downregulating mitochondrial oxygen consumption. Cell Metab. 2006, 3, 187-197. [CrossRef] [PubMed]

24. Vancheri, C. Idiopathic pulmonary fibrosis: An altered fibroblast proliferation linked to cancer biology. Proc. Am. Thorac. Soc. 2012, 9, 153-157. [CrossRef] [PubMed]

25. Ballester, B.; Milara, J.; Cortijo, J. Idiopathic pulmonary fibrosis and lung cancer: Mechanisms and molecular targets. Int. J. Mol. Sci. 2019, 20, 593. [CrossRef] [PubMed]

26. Radisky, D.C.; Kenny, P.A.; Bissell, M.J. Fibrosis and cancer: Do myofibroblasts come also from epithelial cells via EMT? J. Cell. Biochem. 2007, 101, 830-839. [CrossRef]

27. Rubio, K.; Castillo-Negrete, R.; Barreto, G. Non-coding RNAs and nuclear architecture during epithelial-mesenchymal transition in lung cancer and idiopathic pulmonary fibrosis. Cell. Signal. 2020, 70, 109593. [CrossRef]

28. Hanahan, D.; Weinberg, R.A. Hallmarks of cancer: The next generation. Cell 2011, 144, 646-674. [CrossRef]

29. Semenza, G.L. Defining the role of hypoxia-inducible factor 1 in cancer biology and therapeutics. Oncogene 2010, 29, 625-634. [CrossRef]

30. Dewhirst, M.W.; Cao, Y.; Moeller, B. Cycling hypoxia and free radicals regulate angiogenesis and radiotherapy response. Nat. Rev. Cancer 2008, 8, 425-437. [CrossRef]

31. Martinive, P.; Defresne, F.; Bouzin, C.; Saliez, J.; Lair, F.; Grégoire, V.; Michiels, C.; Dessy, C.; Feron, O. Preconditioning of the tumor vasculature and tumor cells by intermittent hypoxia: Implications for anticancer therapies. Cancer Res. 2006, 66, 11736-11744 [CrossRef] [PubMed]

32. Bader, S.B.; Dewhirst, M.W.; Hammond, E.M. Review cyclic hypoxia: An update on its characteristics, methods to measure it and biological implications in cancer. Cancers 2021, 13, 23. [CrossRef] [PubMed]

33. Gozal, D.; Farré, R.; Nieto, F.J. Obstructive sleep apnea and cancer: Epidemiologic links and theoretical biological constructs. Sleep Med. Rev. 2016, 27, 43-55. [CrossRef] [PubMed]

34. Bhaskara, V.K.; Mohanam, I.; Rao, J.S.; Mohanam, S. Intermittent hypoxia regulates stem-like characteristics and differentiation of neuroblastoma cells. PLoS ONE 2012, 7, e30905. [CrossRef]

35. Hao, S.; Zhu, X.; Liu, Z.; Wu, X.; Li, S.; Jiang, P.; Jiang, L. Chronic intermittent hypoxia promoted lung cancer stem cell-like properties via enhancing Bach1 expression. Respir. Res. 2021, 22, 58. [CrossRef] [PubMed]

36. Louie, E.; Nik, S.; Chen, J.-S.; Schmidt, M.; Song, B.; Pacson, C.; Chen, X.F.; Park, S.; Ju, J.; Chen, E.I. Identification of a stem-like cell population by exposing metastatic breast cancer cell lines to repetitive cycles of hypoxia and reoxygenation. Breast Cancer Res. 2010, 12, R94. [CrossRef]

37. Cubillos-Zapata, C.; Martínez-García, M.Á.; Díaz-García, E.; Jaureguizar, A.; Campos-Rodríguez, F.; Sánchez-de-la-Torre, M.; Nagore, E.; Martorell-Calatayud, A.; Blasco, L.H.; Pastor, E.; et al. Obesity attenuates the effect of sleep apnea on active TGF-B1 levels and tumor aggressiveness in patients with melanoma. Sci. Rep. 2020, 10, 15528. [CrossRef]

38. Nanduri, J.; Wang, N.; Yuan, G.; Khan, S.A.; Souvannakitti, D.; Peng, Y.J.; Kumar, G.K.; Garcia, J.A.; Prabhakar, N.R. Intermittent hypoxia degrades HIF- $2 \alpha$ via calpains resulting in oxidative stress: Implications for recurrent apnea-induced morbidities. Proc. Natl. Acad. Sci. USA 2009, 106, 1199-1204. [CrossRef]

39. Prabhakar, N.R.; Peng, Y.J.; Nanduri, J. Hypoxia-inducible factors and obstructive sleep apnea. J. Clin. Invest. 2020, 130, 5042-5051. [CrossRef] 
40. Chandel, N.S.; McClintock, D.S.; Feliciano, C.E.; Wood, T.M.; Melendez, J.A.; Rodriguez, A.M.; Schumacker, P.T. Reactive oxygen species generated at mitochondrial Complex III stabilize hypoxia-inducible factor- $1 \alpha$ during hypoxia: $\mathrm{A}$ mechanism of $\mathrm{O}_{2}$ sensing. J. Biol. Chem. 2000, 275, 25130-25138. [CrossRef] [PubMed]

41. Saikolappan, S.; Kumar, B.; Shishodia, G.; Koul, S.; Koul, H.K. Reactive oxygen species and cancer: A complex interaction. Cancer Lett. 2019, 452, 132-143. [CrossRef]

42. Warburg, O.; Wind, F.; Negelein, E. The metabolism of tumors in the body. J. Gen. Physiol. 1927, 8, 519-530. [CrossRef]

43. Lunt, S.Y.; Vander Heiden, M.G. Aerobic glycolysis: Meeting the metabolic requirements of cell proliferation. Annu. Rev. Cell Dev. Biol. 2011, 27, 441-464. [CrossRef]

44. Gatenby, R.A.; Gillies, R.J. Why do cancers have high aerobic glycolysis? Nat. Rev. Cancer 2004, 4, 891-899. [CrossRef]

45. DeBerardinis, R.J.; Chandel, N.S. We need to talk about the Warburg effect. Nat. Metab. 2020, 2, 127-129. [CrossRef] [PubMed]

46. Lee, P.; Chandel, N.S.; Simon, M.C. Cellular adaptation to hypoxia through hypoxia inducible factors and beyond. Nat. Rev. Mol. Cell Biol. 2020, 21, 268-283. [CrossRef] [PubMed]

47. DeBerardinis, R.J.; Chandel, N.S. Fundamentals of cancer metabolism. Sci. Adv. 2016, 2, e1600200. [CrossRef] [PubMed]

48. Wise, D.R.; Thompson, C.B. Glutamine addiction: A new therapeutic target in cancer. Trends Biochem. Sci. 2010, 35, 427-433. [CrossRef] [PubMed]

49. Van den Heuvel, A.P.J.; Jing, J.; Wooster, R.F.; Bachman, K.E. Analysis of glutamine dependency in non-small cell lung cancer: GLS1 splice variant GAC is essential for cancer cell growth. Cancer Biol. Ther. 2012, 13, 1185-1194. [CrossRef]

50. Durán, R.V.; Oppliger, W.; Robitaille, A.M.; Heiserich, L.; Skendaj, R.; Gottlieb, E.; Hall, M.N. Glutaminolysis Activates RagmTORC1 Signaling. Mol. Cell 2012, 47, 349-358. [CrossRef]

51. Cervantes-Madrid, D.; Romero, Y.; Dueñas-González, A. Reviving Lonidamine and 6-diazo-5-oxo-1-norleucine to be used in combination for metabolic cancer therapy. Biomed Res. Int. 2015, 2015, 690492. [CrossRef]

52. Zhong, H.; De Marzo, A.M.; Laughner, E.; Lim, M.; Hilton, D.A.; Zagzag, D.; Buechler, P.; Isaacs, W.B.; Semenza, G.L.; Simons, J.W. Overexpression of hypoxia-inducible factor $1 \alpha$ in common human cancers and their metastases. Cancer Res. 1999, 59, $5830-5835$.

53. Holmquist-Mengelbier, L.; Fredlund, E.; Löfstedt, T.; Noguera, R.; Navarro, S.; Nilsson, H.; Pietras, A.; Vallon-Christersson, J.; Borg, A.; Gradin, K.; et al. Recruitment of HIF- $1 \alpha$ and HIF- $2 \alpha$ to common target genes is differentially regulated in neuroblastoma: HIF-2 $\alpha$ promotes an aggressive phenotype. Cancer Cell 2006, 10, 413-423. [CrossRef]

54. Bracken, C.P.; Fedele, A.O.; Linke, S.; Balrak, W.; Lisy, K.; Whitelaw, M.L.; Peet, D.J. Cell-specific regulation of hypoxia-inducible factor (HIF)-1alpha and HIF-2alpha stabilization and transactivation in a graded oxygen environment. J. Biol. Chem. 2006, 281, 22575-22585. [CrossRef] [PubMed]

55. Petrella, B.L.; Lohi, J.; Brinckerhoff, C.E. Identification of membrane type-1 matrix metalloproteinase as a target of hypoxiainducible factor-2 $\alpha$ in von Hippel-Lindau renal cell carcinoma. Oncogene 2005, 24, 1043-1052. [CrossRef] [PubMed]

56. Warnecke, C.; Zaborowska, Z.; Kurreck, J.; Erdmann, V.A.; Frei, U.; Wiesener, M.; Eckardt, K. Differentiating the functional role of hypoxia-inducible factor (HIF)- $1 \alpha$ and HIF- $2 \alpha$ (EPAS-1) by the use of RNA interference: Erythropoietin is a HIF-2 $\alpha$ target gene in Hep3B and Kelly cells. FASEB J. 2004, 18, 1462-1464. [CrossRef]

57. Sato, M.; Tanaka, T.; Maemura, K.; Uchiyama, T.; Sato, H.; Maeno, T.; Suga, T.; Iso, T.; Ohyama, Y.; Arai, M.; et al. The PAI-1 gene as a direct target of endothelial PAS domain protein-1 in adenocarcinoma A549 cells. Am. J. Respir. Cell Mol. Biol. 2004, 31, 209-215. [CrossRef] [PubMed]

58. Compernolle, V.; Brusselmans, K.; Acker, T.; Hoet, P.; Tjwa, M.; Beck, H.; Plaisance, S.; Dor, Y.; Keshet, E.; Lupu, F.; et al. Loss of HIF-2alpha and inhibition of VEGF impair fetal lung maturation, whereas treatment with VEGF prevents fatal respiratory distress in premature mice. Nat. Med. 2002, 8, 702-710. [CrossRef] [PubMed]

59. Giatromanolaki, A.; Koukourakis, M.I.; Sivridis, E.; Turley, H.; Talks, K.; Pezzella, F.; Gatter, K.C.; Harris, A.L. Relation of hypoxia inducible factor 1 alpha and 2 alpha in operable non-small cell lung cancer to angiogenic/molecular profile of tumours and survival. Br. J. Cancer 2001, 85, 881-890. [CrossRef] [PubMed]

60. Pasanen, A.; Heikkilä, M.; Rautavuoma, K.; Hirsilä, M.; Kivirikko, K.I.; Myllyharju, J. Hypoxia-inducible factor (HIF)-3 $\alpha$ is subject to extensive alternative splicing in human tissues and cancer cells and is regulated by HIF-1 but not HIF-2. Int. J. Biochem. Cell Biol. 2010, 42, 1189-1200. [CrossRef]

61. Heikkilä, M.; Pasanen, A.; Kivirikko, K.I.; Myllyharju, J. Roles of the human hypoxia-inducible factor (HIF)-3 $\alpha$ variants in the hypoxia response. Cell. Mol. Life Sci. 2011, 68, 3885-3901. [CrossRef]

62. Romero, Y.; Castillejos-López, M.; Romero-Garciá, S.; Aguayo, A.S.; Herrera, I.; Garcia-Martin, M.O.; Torres-Espíndola, L.M.; Negrete-Garciá, M.C.; Olvera, A.C.; Huerta-Cruz, J.C.; et al. Antitumor Therapy under Hypoxic Microenvironment by the Combination of 2-Methoxyestradiol and Sodium Dichloroacetate on Human Non-Small-Cell Lung Cancer. Oxid. Med. Cell. Longev. 2020, 2020, 3176375. [CrossRef]

63. Esteller, M. Epigenetics in cancer. N. Engl. J. Med. 2008, 358, 1148-1159. [CrossRef]

64. Fraga, M.F.; Esteller, M. Epigenetics and aging: The targets and the marks. Trends Genet. 2007, 23, 413-418. [CrossRef]

65. Thienpont, B.; Steinbacher, J.; Zhao, H.; D’Anna, F.; Kuchnio, A.; Ploumakis, A.; Ghesquière, B.; Van Dyck, L.; Boeckx, B.; Schoonjans, L.; et al. Tumour hypoxia causes DNA hypermethylation by reducing TET activity. Nature 2016, 537, 63-68. [CrossRef] [PubMed]

66. Batie, M.; Frost, J.; Frost, M.; Wilson, J.W.; Schofield, P.; Rocha, S. Hypoxia induces rapid changes to histone methylation and reprograms chromatin. Science 2019, 363, 1222-1226. [CrossRef] [PubMed] 
67. Wu, M.Z.; Tsai, Y.P.; Yang, M.H.; Huang, C.H.; Chang, S.Y.; Chang, C.C.; Teng, S.C.; Wu, K.J. Interplay between HDAC3 and WDR5 Is Essential for Hypoxia-Induced Epithelial-Mesenchymal Transition. Mol. Cell 2011, 43, 811-822. [CrossRef]

68. Swinson, D.E.B.; Jones, J.L.; Cox, G.; Richardson, D.; Harris, A.L.; O’Byrne, K.J. Hypoxia-inducible factor-1 $\alpha$ in non small cell lung cancer: Relation to growth factor, protease and apoptosis pathways. Int. J. Cancer 2004, 111, 43-50. [CrossRef]

69. Liu, G.Y.; Sabatini, D.M. mTOR at the nexus of nutrition, growth, ageing and disease. Nat. Rev. Mol. Cell Biol. 2020, 21, 183-203. [CrossRef] [PubMed]

70. Wouters, B.G.; Koritzinsky, M. Hypoxia signalling through mTOR and the unfolded protein response in cancer. Nat. Rev. Cancer 2008, 8, 851-864. [CrossRef] [PubMed]

71. Graeber, T.G.; Osmanian, C.; Jacks, T.; Housman, D.E.; Koch, C.J.; Lowe, S.W.; Giaccia, A.J. Hypoxia-mediated selection of cells with diminished apoptotic potential in solid tumours. Nature 1996, 379, 88-91. [CrossRef] [PubMed]

72. Lum, J.J.; DeBerardinis, R.J.; Thompson, C.B. Autophagy in metazoans: Cell survival in the land of plenty. Nat. Rev. Mol. Cell Biol. 2005, 6, 439-448. [CrossRef]

73. Chen, X.; Iliopoulos, D.; Zhang, Q.; Tang, Q.; Greenblatt, M.B.; Hatziapostolou, M.; Lim, E.; Tam, W.L.; Ni, M.; Chen, Y.; et al XBP1 promotes triple-negative breast cancer by controlling the HIF1 $\alpha$ pathway. Nature 2014, 508, 103-107. [CrossRef] [PubMed]

74. Koumenis, C.; Wouters, B.G. "Translating" tumor hypoxia: Unfolded protein response (UPR)-dependent and UPR-independent pathways. Mol. Cancer Res. 2006, 4, 423-436. [CrossRef]

75. Hetz, C.; Zhang, K.; Kaufman, R.J. Mechanisms, regulation and functions of the unfolded protein response. Nat. Rev. Mol. Cell Biol. 2020, 21, 421-438. [CrossRef] [PubMed]

76. Kobayashi, S.; Boggon, T.J.; Dayaram, T.; Jänne, P.A.; Kocher, O.; Meyerson, M.; Johnson, B.E.; Eck, M.J.; Tenen, D.G.; Halmos, B. EGFR Mutation and Resistance of Non-Small-Cell Lung Cancer to Gefitinib. N. Engl. J. Med. 2005, 352, 786-792. [CrossRef]

77. Kozlova, N.; Mennerich, D.; Samoylenko, A.; Dimova, E.Y.; Koivunen, P.; Biterova, E.; Richter, K.; Hassinen, A.; Kellokumpu, S.; Manninen, A.; et al. The pro-oncogenic adaptor CIN85 acts as an inhibitory binding partner of hypoxia-inducible factor prolyl hydroxylase 2. Cancer Res. 2019, 79, 4042-4056. [CrossRef]

78. Li, D.; Shimamura, T.; Ji, H.; Chen, L.; Haringsma, H.J.; McNamara, K.; Liang, M.C.; Perera, S.A.; Zaghlul, S.; Borgman, C.L.; et al. Bronchial and Peripheral Murine Lung Carcinomas Induced by T790M-L858R Mutant EGFR Respond to HKI-272 and Rapamycin Combination Therapy. Cancer Cell 2007, 12, 81-93. [CrossRef]

79. Zundel, W.; Schindler, C.; Haas-Kogan, D.; Koong, A.; Kaper, F.; Chen, E.; Gottschalk, A.R.; Ryan, H.E.; Johnson, R.S.; Jefferson, A.B.; et al. Loss of PTEN facilitates HIF-1-mediated gene expression. Genes Dev. 2000, 14, 391-396. [CrossRef]

80. Bhandari, V.; Hoey, C.; Liu, L.Y.; Lalonde, E.; Ray, J.; Livingstone, J.; Lesurf, R.; Shiah, Y.J.; Vujcic, T.; Huang, X.; et al. Molecular landmarks of tumor hypoxia across cancer types. Nat. Genet. 2019, 51, 308-318. [CrossRef]

81. Kondo, K.; Klco, J.; Nakamura, E.; Lechpammer, M.; Kaelin, W.G. Inhibition of HIF is necessary for tumor suppression by the von Hippel-Lindau protein. Cancer Cell 2002, 1, 237-246. [CrossRef]

82. Xing, F.; Saidou, J.; Watabe, K. Cancer associated fibroblasts (CAFs) in tumor microenvironment. Front. Biosci. Landmark Ed. 2010, 15, 166-179. [CrossRef]

83. Kalluri, R.; Zeisberg, M. Fibroblasts in cancer. Nat. Rev. Cancer 2006, 6, 392-401. [CrossRef]

84. Giulia, B.; David, A.T. Diversity and Biology of Cancer-Associated Fibroblasts. Physiol. Rev. 2020, 53, $1689-1699$.

85. Barbazan, J.; Pérez-González, C.; Gómez-González, M.; Dedenon, M.; Richon, S.; Latorre, E.; Serra, M.; Mariani, P.; Descroix, S.; Sens, P.; et al. Cancer-associated fibroblasts actively compress cancer cells and modulate mechanotransduction. bioRxiv 2021. [CrossRef]

86. Miyoshi, A.; Kitajima, Y.; Ide, T.; Ohtaka, K.; Nagasawa, H.; Uto, Y.; Hori, H.; Miyazaki, K. Hypoxia accelerates cancer invasion of hepatoma cells by upregulating MMP expression in an HIF-1 $\alpha$-independent manner. Int. J. Oncol. 2006, 29, 1533-1539. [CrossRef] [PubMed]

87. Lukacova, S.; Khalil, A.A.; Overgaard, J.; Alsner, J.; Horsman, M.R. Relationship between radiobiological hypoxia in a C3H mouse mammary carcinoma and osteopontin levels in mouse serum. Int. J. Radiat. Biol. 2005, 81, 937-944. [CrossRef] [PubMed]

88. Le Jeune, I.; Gribbin, J.; West, J.; Smith, C.; Cullinan, P.; Hubbard, R. The incidence of cancer in patients with idiopathic pulmonary fibrosis and sarcoidosis in the UK. Respir. Med. 2007, 101, 2534-2540. [CrossRef]

89. Hubbard, R.; Venn, A.; Lewis, S.; Britton, J. Lung cancer and cryptogenic fibrosing alveolitis: A population-based cohort study. Am. J. Respir. Crit. Care Med. 2000, 161, 5-8. [CrossRef]

90. Selman, M.; TE, K., Jr.; Pardo, A.; King, J.; Pardo, A. Idiopathic pulmonary fibrosis: Prevailing and evolving hypotheses about its pathogenesis and implications for therapy. Ann. Intern. Med. 2001, 134, 136-151. [CrossRef]

91. King, T.E.; Pardo, A.; Selman, M.M. Idiopathic pulmonary fibrosis. Lancet 2011, 378, 1949-1961. [CrossRef]

92. Selman, M.; Pardo, A. The leading role of epithelial cells in the pathogenesis of idiopathic pulmonary fibrosis. Cell. Signal. 2020, 66, 109482. [CrossRef]

93. Selman, M.; Pardo, A. Revealing the pathogenic and aging-related mechanisms of the enigmatic idiopathic pulmonary fibrosis: An integral model. Am. J. Respir. Crit. Care Med. 2014, 189, 1161-1172. [CrossRef] [PubMed]

94. Selman, M.; Romero, Y.; Pardo, A. Aging and IPF: What Is the Link? In BT_Idiopathic Pulmonary Fibrosis: A Comprehensive Clinical Guide; Meyer, K.C., Nathan, S.D., Eds.; Humana Press: Totowa, NJ, USA, 2014; pp. 259-279, ISBN 978-1-62703-682-5.

95. Selman, M.; Pardo, A. Role of epithelial cells in idiopathic pulmonary fibrosis: From innocent targets to serial killers. Proc. Am. Thorac. Soc. 2006, 3, 364-372. [CrossRef] 
96. Sørensen, B.S.; Horsman, M.R. Tumor Hypoxia: Impact on Radiation Therapy and Molecular Pathways. Front. Oncol. 2020, 10,1-11. [CrossRef]

97. Rosas, I.O.; Richards, T.J.; Konishi, K.; Zhang, Y.; Gibson, K.; Lokshin, A.E. MMP1 and MMP7 as potential peripheral blood biomarkers in idiopathic pulmonary fibrosis. PLoS Med. 2008, 5. [CrossRef]

98. Pardo, A.; Gibson, K.; Cisneros, J.; Richards, T.J.; Yang, Y.; Becerril, C.; Yousem, S.; Herrera, I.; Ruiz, V.; Selman, M.; et al. Up-regulation and profibrotic role of osteopontin in human idiopathic pulmonary fibrosis. PLoS Med. 2005, 2, 891-903. [CrossRef]

99. Sørensen, B.S.; Alsner, J.; Overgaard, J.; Horsman, M.R. Hypoxia induced expression of endogenous markers in vitro is highly influenced by pH. Radiother. Oncol. 2007, 83, 362-366. [CrossRef]

100. Placido, L.; Romero, Y.; Maldonado, M.; Toscano-Marquez, F.; Ramírez, R.; Calyeca, J.; Mora, A.L.; Selman, M.; Pardo, A. Loss of mt1-mmp in alveolar epithelial cells exacerbates pulmonary fibrosis. Int. J. Mol. Sci. 2021, 22, 2923. [CrossRef] [PubMed]

101. Oblander, S.A.; Zhou, Z.; Gálvez, B.G.; Starcher, B.; Shannon, J.M.; Durbeej, M.; Arroyo, A.G.; Tryggvason, K.; Apte, S.S. Distinctive functions of membrane type 1 matrix-metalloprotease (MT1-MMP or MMP-14) in lung and submandibular gland development are independent of its role in pro-MMP-2 activation. Dev. Biol. 2005, 277, 255-269. [CrossRef] [PubMed]

102. Reyfman, P.A.; Walter, J.M.; Joshi, N.; Anekalla, K.R.; McQuattie-Pimentel, A.C.; Chiu, S.; Fernandez, R.; Akbarpour, M.; Chen, C.I.; Ren, Z.; et al. Single-cell transcriptomic analysis of human lung provides insights into the pathobiology of pulmonary fibrosis. Am. J. Respir. Crit. Care Med. 2019, 199, 1517-1536. [CrossRef]

103. Misharin, A.V.; Morales-Nebreda, L.; Reyfman, P.A.; Cuda, C.M.; Walter, J.M.; McQuattie-Pimentel, A.C.; Chen, C.I.; Anekalla, K.R.; Joshi, N.; Williams, K.J.N.; et al. Monocyte-derived alveolar macrophages drive lung fibrosis and persist in the lung over the life span. J. Exp. Med. 2017, 214, 2387-2404. [CrossRef]

104. Lavin, Y.; Winter, D.; Blecher-Gonen, R.; David, E.; Keren-Shaul, H.; Merad, M.; Jung, S.; Amit, I. Tissue-resident macrophage enhancer landscapes are shaped by the local microenvironment. Cell 2014, 159, 1312-1326. [CrossRef] [PubMed]

105. Weinberg, S.E.; Sena, L.A.; Chandel, N.S. Mitochondria in the regulation of innate and adaptive immunity. Immunity 2015, 42, 406-417. [CrossRef]

106. Clerici, C.; Planès, C. Gene regulation in the adaptive process to hypoxia in lung epithelial cells. Am. J. Physiol. Lung Cell. Mol. Physiol. 2009, 296, L267-L274. [CrossRef] [PubMed]

107. Krick, S.; Eul, B.G.; Hänze, J.; Savai, R.; Grimminger, F.; Seeger, W.; Rose, F. Role of hypoxia-inducible factor-1alpha in hypoxiainduced apoptosis of primary alveolar epithelial type II cells. Am. J. Respir. Cell Mol. Biol. 2005, 32, 395-403. [CrossRef]

108. Jain, M.; Sznajder, J.I. Effects of hypoxia on the alveolar epithelium. Proc. Am. Thorac. Soc. 2005, 2, 202-205. [CrossRef]

109. Autilio, C.; Pérez-Gil, J. Understanding the principle biophysics concepts of pulmonary surfactant in health and disease. Arch. Dis. Child. Fetal Neonatal Ed. 2019, 104, F443-F451. [CrossRef] [PubMed]

110. Lopez-Rodriguez, E.; Boden, C.; Echaide, M.; Perez-Gil, J.; Kolb, M.; Gauldie, J.; Maus, U.A.; Ochs, M.; Knudsen, L. Surfactant dysfunction during overexpression of TGF- $\beta 1$ precedes profibrotic lung remodeling in vivo. Am. J. Physiol. Lung Cell. Mol. Physiol. 2016, 310, L1260-L1271. [CrossRef] [PubMed]

111. Ruwisch, J.; Sehlmeyer, K.; Roldan, N.; Garcia-Alvarez, B.; Perez-Gil, J.; Weaver, T.E.; Ochs, M.; Knudsen, L.; Lopez-Rodriguez, E. Air space distension precedes spontaneous fibrotic remodeling and impaired cholesterol metabolism in the absence of surfactant protein C. Am. J. Respir. Cell Mol. Biol. 2020, 62, 466-478. [CrossRef]

112. Vazquez-De-Lara, L.G.; Tlatelpa-Romero, B.; Romero, Y.; Fernández-Tamayo, N.; Vazquez-De-Lara, F.; Justo-Janeiro, J.M.; GarciaCarrasco, M.; Paredes, R.D.L.R.; Cisneros-Lira, J.G.; Mendoza-Milla, C.; et al. Phosphatidylethanolamine induces an antifibrotic phenotype in normal human lung fibroblasts and ameliorates bleomycin-induced lung fibrosis in mice. Int. J. Mol. Sci. 2018, 19, 2758. [CrossRef]

113. Uhal, B.D.; Joshi, I.; Hughes, W.F.; Ramos, C.; Pardo, A.; Selman, M. Alveolar epithelial cell death adjacent to underlying myofibroblasts in advanced fibrotic human lung. Am. J. Physiol. Lung Cell. Mol. Physiol. 1998, 275, 1192-1199. [CrossRef] [PubMed]

114. Tzouvelekis, A.; Harokopos, V.; Paparountas, T.; Oikonomou, N.; Chatziioannou, A.; Vilaras, G.; Tsiambas, E.; Karameris, A.; Bouros, D.; Aidinis, V. Comparative expression profiling in pulmonary fibrosis suggests a role of hypoxia-inducible factor-1 $\alpha$ in disease pathogenesis. Am. J. Respir. Crit. Care Med. 2007, 176, 1108-1119. [CrossRef] [PubMed]

115. Shochet, G.E.; Bardenstein-Wald, B.; McElroy, M.; Kukuy, A.; Surber, M.; Edelstein, E.; Pertzov, B.; Kramer, M.R.; Shitrit, D. Hypoxia inducible factor 1a supports a pro-fibrotic phenotype loop in idiopathic pulmonary fibrosis. Int. J. Mol. Sci. 2021, 22, 3331. [CrossRef] [PubMed]

116. Ramírez, G.; Hagood, J.S.; Sanders, Y.; Ramírez, R.; Becerril, C.; Segura, L. Absence of Thy-1 results in TGF- $\beta$ induced MMP-9 expression and confers a profibrotic phenotype to human lung fibroblasts. Lab. Invest. 2011, 91, 1206-1218. [CrossRef] [PubMed]

117. Robinson, C.M.; Neary, R.; Levendale, A.; Watson, C.J.; Baugh, J.A. Hypoxia-induced DNA hypermethylation in human pulmonary fibroblasts is associated with Thy-1 promoter methylation and the development of a pro-fibrotic phenotype. Respir. Res. 2012, 13, 74. [CrossRef] [PubMed]

118. Hagood, J.S.; Prabhakaran, P.; Kumbla, P.; Salazar, L.; MacEwen, M.W.; Barker, T.H. Loss of fibroblast Thy-1 expression correlates with lung fibrogenesis. Am. J. Pathol. 2005, 167, 365-379. [CrossRef]

119. Rege, T.A.; Hagood, J.S. Thy-1 as a regulator of cell-cell and cell-matrix interactions in axon regeneration, apoptosis, adhesion, migration, cancer, and fibrosis. FASEB J. 2006, 20, 1045-1054. [CrossRef] 
120. Aquino-Gálvez, A.; González-Ávila, G.; Jiménez-Sánchez, L.L.; Maldonado-Martínez, H.A.; Cisneros, J.; Toscano-Marquez, F.; Castillejos-López, M.; Torres-Espíndola, L.M.; Velázquez-Cruz, R.; Rodríguez, V.H.O.; et al. Dysregulated expression of hypoxiainducible factors augments myofibroblasts differentiation in idiopathic pulmonary fibrosis. Respir. Res. 2019, 20, 130. [CrossRef]

121. Selman, M.; Pardo, A. Fibroageing: An ageing pathological feature driven by dysregulated extracellular matrix-cell mechanobiology. Ageing Res. Rev. 2021, 70, 101393. [CrossRef]

122. Cool, C.D.; Groshong, S.D.; Rai, P.R.; Henson, P.M.; Stewart, J.S.; Brown, K.K. Fibroblast foci are not discrete sites of lung injury or repair: The fibroblast reticulum. Am. J. Respir. Crit. Care Med. 2006, 174, 654-658. [CrossRef] [PubMed]

123. Vancheri, C. Common pathways in idiopathic pulmonary fibrosis and cancer. Eur. Respir. Rev. 2013, 22, 265-272. [CrossRef]

124. Braun, R.K.; Broytman, O.; Braun, F.M.; Brinkman, J.A.; Clithero, A.; Modi, D.; Pegelow, D.F.; Eldridge, M.; Teodorescu, M. Chronic intermittent hypoxia worsens bleomycin-induced lung fibrosis in rats. Respir. Physiol. Neurobiol. 2018, 256, 97-108. [CrossRef]

125. Lancaster, L.H.; Mason, W.R.; Parnell, J.A.; Rice, T.W.; Loyd, J.E.; Milstone, A.P.; Collard, H.R.; Malow, B.A. Obstructive Sleep Apnea Is Common in Idiopathic Pulmonary Fibrosis. Chest 2009, 136, 772-778. [CrossRef]

126. Schiza, S.; Mermigkis, C.; Margaritopoulos, G.A.; Daniil, Z.; Harari, S.; Poletti, V.; Renzoni, E.A.; Torre, O.; Visca, D.; Bouloukaki, I.; et al. Idiopathic pulmonary fibrosis and sleep disorders: No longer strangers in the night. Eur. Respir. Rev. 2015, 24, 327-339. [CrossRef] [PubMed]

127. Romero, Y.; Bueno, M.; Ramirez, R.; Álvarez, D.; Sembrat, J.C.; Goncharova, E.A.; Rojas, M.; Selman, M.; Mora, A.L.; Pardo, A. mTORC1 activation decreases autophagy in aging and idiopathic pulmonary fibrosis and contributes to apoptosis resistance in IPF fibroblasts. Aging Cell 2016, 15, 1103-1112. [CrossRef]

128. Nigdelioglu, R.; Hamanaka, R.B.; Meliton, A.Y.; O’Leary, E.; Witt, L.J.; Cho, T.; Sun, K.; Bonham, C.; Wu, D.; Woods, P.S.; et al. Transforming Growth Factor (TGF)- $\beta$ Promotes de Novo Serine Synthesis for Collagen Production. J. Biol. Chem. 2016, 291, 27239-27251. [CrossRef]

129. Kottmann, R.M.; Kulkarni, A.A.; Smolnycki, K.A.; Lyda, E.; Dahanayake, T.; Salibi, R.; Honnons, S.; Jones, C.; Isern, N.G.; $\mathrm{Hu}$, J.Z.; et al. Lactic acid is elevated in idiopathic pulmonary fibrosis and induces myofibroblast differentiation via $\mathrm{pH}$-dependent activation of transforming growth factor- $\beta$. Am. J. Respir. Crit. Care Med. 2012, 186, 740-751. [CrossRef] [PubMed]

130. Gopu, V.; Fan, L.; Shetty, R.S.; Nagaraja, M.R.; Shetty, S. Caveolin-1 scaffolding domain peptide regulates glucose metabolism in lung fibrosis. JCI Insight 2020, 5, e137969. [CrossRef]

131. Xie, N.; Tan, Z.; Banerjee, S.; Cui, H.; Ge, J.; Liu, R.-M.; Bernard, K.; Thannickal, V.J.; Liu, G. Glycolytic Reprogramming in Myofibroblast Differentiation and Lung Fibrosis. Am. J. Respir. Crit. Care Med. 2015, 192, 1462-1474. [CrossRef] [PubMed]

132. Cho, S.J.; Moon, J.-S.; Lee, C.-M.; Choi, A.M.K.; Stout-Delgado, H.W. Glucose Transporter 1-Dependent Glycolysis Is Increased during Aging-Related Lung Fibrosis, and Phloretin Inhibits Lung Fibrosis. Am. J. Respir. Cell Mol. Biol. 2017, 56, 521-531. [CrossRef]

133. Han, S.; Chandel, N.S. Lessons from Cancer Metabolism for Pulmonary Arterial Hypertension and Fibrosis. Am. J. Respir. Cell Mol. Biol. 2021, 65, 1-38. [CrossRef]

134. Herrera, I.; Cisneros, J.; Maldonado, M.; Ramírez, R.; Ortiz-Quintero, B.; Anso, E. Matrix metalloproteinase (MMP)-1 induces lung alveolar epithelial cell migration and proliferation, protects from apoptosis, and represses mitochondrial oxygen consumption. J. Biol. Chem. 2013, 288, 25964-25975. [CrossRef] [PubMed]

135. Mohyeldin, A.; Garzón-Muvdi, T.; Quiñones-Hinojosa, A. Oxygen in stem cell biology: A critical component of the stem cell niche. Cell Stem Cell 2010, 7, 150-161. [CrossRef] [PubMed]

136. Xi, Y.; Kim, T.; Brumwell, A.N.; Driver, I.H.; Wei, Y.; Tan, V.; Jackson, J.R.; Xu, J.; Lee, D.K.; Gotts, J.E.; et al. Local lung hypoxia determines epithelial fate decisions during alveolar regeneration. Nat. Cell Biol. 2017, 19, 904-914. [CrossRef]

137. Kobayashi, Y.; Tata, A.; Konkimalla, A.; Katsura, H.; Lee, R.F.; Ou, J.; Banovich, N.E.; Kropski, J.A.; Tata, P.R. Persistence of a regeneration-associated, transitional alveolar epithelial cell state in pulmonary fibrosis. Nat. Cell Biol. 2020, 22, 934-946. [CrossRef] [PubMed]

138. Jin, Y.; Kato, T.; Furu, M.; Nasu, A.; Kajita, Y.; Mitsui, H.; Ueda, M.; Aoyama, T.; Nakayama, T.; Nakamura, T.; et al. Mesenchymal stem cells cultured under hypoxia escape from senescence via down-regulation of p16 and extracellular signal regulated kinase. Biochem. Biophys. Res. Commun. 2010, 391, 1471-1476. [CrossRef]

139. Lan, Y.W.; Choo, K.B.; Chen, C.M.; Hung, T.H.; Chen, Y.B.; Hsieh, C.H.; Kuo, H.P.; Chong, K.Y. Hypoxia-preconditioned mesenchymal stem cells attenuate bleomycin-induced pulmonary fibrosis. Stem Cell Res. Ther. 2015, 6, 1-17. [CrossRef] [PubMed]

140. Desai, T.J.; Brownfield, D.G.; Krasnow, M.A. Alveolar progenitor and stem cells in lung development, renewal and cancer. Nature 2014, 507, 190-194. [CrossRef]

141. Villaseñor-Altamirano, A.B.; Moretto, M.; Maldonado, M.; Zayas-Del Moral, A.; Munguía-Reyes, A.; Romero, Y.; García-Sotelo, J.S.; Aguilar, L.A.; Aldana-Assad, O.; Engelen, K.; et al. PulmonDB: A curated lung disease gene expression database. Sci. Rep. 2020, 10, 514. [CrossRef]

142. Nabhan, A.N.; Brownfield, D.G.; Harbury, P.B.; Krasnow, M.A.; Desai, T.J. Single-cell Wnt signaling niches maintain stemness of alveolar type 2 cells. Science 2018, 359, 1118-1123. [CrossRef]

143. Zacharias, W.J.; Frank, D.B.; Zepp, J.A.; Morley, M.P.; Alkhaleel, F.A.; Kong, J.; Zhou, S.; Cantu, E.; Morrisey, E.E. Regeneration of the lung alveolus by an evolutionarily conserved epithelial progenitor. Nature 2018, 555, 251-255. [CrossRef]

144. Scadden, D.T. The stem-cell niche as an entity of action. Nature 2006, 441, 1075-1079. [CrossRef] 
145. Covello, K.L.; Kehler, J.; Yu, H.; Gordan, J.D.; Arsham, A.M.; Hu, C.-J.; Labosky, P.A.; Simon, M.C.; Keith, B. HIF-2alpha regulates Oct-4: Effects of hypoxia on stem cell function, embryonic development, and tumor growth. Genes Dev. 2006, 20, 557-570. [CrossRef]

146. Gustafsson, M.V.; Zheng, X.; Pereira, T.; Gradin, K.; Jin, S.; Lundkvist, J.; Ruas, J.L.; Poellinger, L.; Lendahl, U.; Bondesson, M. Hypoxia requires notch signaling to maintain the undifferentiated cell state. Dev. Cell 2005, 9, 617-628. [CrossRef]

147. Simon, M.C.; Keith, B. The role of oxygen availability in embryonic development and stem cell function. Nat. Rev. Mol. Cell Biol. 2008, 9, 285-296. [CrossRef]

148. Parmar, K.; Mauch, P.; Vergilio, J.-A.; Sackstein, R.; Down, J.D. Distribution of hematopoietic stem cells in the bone marrow according to regional hypoxia. Proc. Natl. Acad. Sci. USA 2007, 104, 5431-5436. [CrossRef] [PubMed]

149. Jarecki, J.; Johnson, E.; Krasnow, M.A. Oxygen regulation of airway branching in Drosophila is mediated by branchless FGF. Cell 1999, 99, 211-220. [CrossRef]

150. Dunwoodie, S.L. The Role of Hypoxia in Development of the Mammalian Embryo. Dev. Cell 2009, 17, 755-773. [CrossRef] [PubMed]

151. Huang, Y.; Kapere Ochieng, J.; Kempen, M.B.; Munck, A.B.; Swagemakers, S.; van Ijcken, W.; Grosveld, F.; Tibboel, D.; Rottier, R.J. Hypoxia inducible factor $3 \alpha$ plays a critical role in alveolarization and distal epithelial cell differentiation during mouse lung development. PLoS ONE 2013, 8, e57695. [CrossRef] [PubMed]

152. Schneider, J.L.; Rowe, J.H.; Garcia-de-Alba, C.; Kim, C.F.; Sharpe, A.H.; Haigis, M.C. The aging lung: Physiology, disease, and immunity. Cell 2021, 184, 1990-2019. [CrossRef] [PubMed]

153. Strunz, M.; Simon, L.M.; Ansari, M.; Kathiriya, J.J.; Angelidis, I.; Mayr, C.H.; Tsidiridis, G.; Lange, M.; Mattner, L.F.; Yee, M.; et al. Alveolar regeneration through a Krt8+ transitional stem cell state that persists in human lung fibrosis. Nat. Commun. 2020, 11, 3559. [CrossRef]

154. Adams, T.S.; Schupp, J.C.; Poli, S.; Ayaub, E.A.; Neumark, N.; Ahangari, F.; Chu, S.G.; Raby, B.A.; DeIuliis, G.; Januszyk, M.; et al. Single-cell RNA-seq reveals ectopic and aberrant lung-resident cell populations in idiopathic pulmonary fibrosis. Sci. Adv. 2020, 6, eaba1983. [CrossRef]

155. Li, J.; Wang, Z.; Chu, Q.; Jiang, K.; Li, J.; Tang, N. The Strength of Mechanical Forces Determines the Differentiation of Alveolar Epithelial Cells. Dev. Cell 2018, 44, 297-312.e5. [CrossRef]

156. Becerril, C.; Montaño, M.; Cisneros, J.; Mendoza-Milla, C.; Pardo, A.; Ortiz-Quintero, B.; Selman, M.; Ramos, C. Mesenchymalepithelial transition in fibroblasts of human normal lungs and interstitial lung diseases. Biomolecules 2021, 11, 378. [CrossRef] [PubMed]

157. Wilson, W.R.; Hay, M.P. Targeting hypoxia in cancer therapy. Nat. Rev. Cancer 2011, 11, 393-410. [CrossRef] [PubMed] 